DOI: https://doi.org/10.34069/AI/2021.46.10.30

How to Cite:

Burdina, A.A., Bondarenko, A.V., Moskvicheva, N.V., \& Melik-Aslanova, N.O. (2021). Management of complex economic security of enterprises: empirical test in Russia. Amazonia Investiga, 10(46), 303-310. https://doi.org/10.34069/AI/2021.46.10.30

\title{
Management of complex economic security of enterprises: empirical test in Russia
}

\section{Управление комплексной экономической безопасностью предприятий: эмпирическая проверка в России}

Received: October 5, $2021 \quad$ Accepted: November 9, 2021

Written by:

Anna A. Burdina ${ }^{112}$

https://www.scopus.com/authid/detail.uri?authorId=57192807996 https://www.elibrary.ru/author_profile.asp?id=76961 https://orcid.org/0000-0002-6983-0796

Anna V. Bondarenko ${ }^{113}$

https://www.scopus.com/authid/detail.uri?authorId=57211386800 https://www.elibrary.ru/author_profile.asp?id=791658 https://orcid.org/0000-0001-8982-7992

Nataliya V. Moskvicheva ${ }^{114}$

https://www.scopus.com/authid/detail.uri?authorId=57192816313 https://www.elibrary.ru/author_profile.asp?id=580983 https://orcid.org/0000-0002-5538-7340

Narmina O. Melik-Aslanova115

https://www.scopus.com/authid/detail.uri?authorId=57216320525 https://www.elibrary.ru/author_profile.asp?id=914533 https://orcid.org/0000-0003-1003-926X

\begin{abstract}
There is a new meaningful interpretation of the concept of "integrated economic security of industrial enterprise"; the problems of analyzing complex economic security are substantiated. Based on the study of the regulatory and legal and methodological support of the process of managing economic security in modern economic and political conditions, generalizations and analysis of existing practice in Russia and abroad, the main shortcomings in approaches to assessing the integrated economic security of industrial enterprises have been identified. The article examines the methods for assessing economic security: matrix, product, operational, dynamic one and methods of assessment based on the market value of the company. The parameters of the integrated economic security of industrial enterprise are classified: financial and economic security, information, technological, material and technical, personnel, epidemiological security,
\end{abstract}

Аннотация

Дана новая содержательная трактовка понятия «комплексная экономическая безопасность промышленного предприятия», обоснованы проблемы анализа комплексной экономической безопасности. Выявлены, на основе изучения нормативно-правового и методического обеспечения процесса управления экономической безопасностью в современных экономических, политических условиях, обобщений и анализа существующей практики в России и за рубежом, основные недостатки в подходах к оценке комплексной экономической безопасности промышленных предприятий. В статье исследованы методы оценки экономической безопасности: матричные, продуктовые, операционные, динамические и методы оценки, основанные на рыночной стоимости компании. Классифицированы параметры комплексной экономической безопасности промышленного предприятия:

\footnotetext{
${ }^{112}$ Doctor in Economic Sciences, Professor, Moscow Aviation Institute (National Research University), Moscow, Russia.

${ }^{113} \mathrm{PhD}$ in Economic Sciences, Associate Professor, Moscow Aviation Institute (National Research University), Moscow, Russia

${ }^{114} \mathrm{PhD}$ in Economic Sciences, Associate Professor, Moscow Aviation Institute (National Research University), Moscow, Russia

${ }^{115} \mathrm{PhD}$ in Economic Sciences, Associate Professor, Moscow Aviation Institute (National Research University), Moscow, Russia.
} 
conceptual model for assessing financial and economic and integrated security of enterprise has been developed. The practical implementation of the proposed developments has been carried out. It is recommended to use the developed model of economic security management as enterprise resource planning (ERP) module of the enterprise system.

Keywords: ERP system, model, financial and economic security, information security, integrated security.

\section{Introduction}

One of the actual problems of industrial enterprises in the context of digitalization of the external and internal environment is management of the economic security of the enterprise. There are many interpretations of this concept in the literature (Fedyanina, 2019; Alferyev and Khusainova, 2020). Analysis of approaches to the concept of economic security of a company reveals the main difference between them, which lies in the depth of introduction into the essence of this category. The above analysis of the definitions of the term "economic security of an enterprise" allows highlighting a number of important features (Gilfanov, 2013; Inchauspe and Cronje, 2020):

- economic security is a dynamic phenomenon;

- $\quad$ economic security of the enterprise directly depends on the stage of the enterprise's life cycle;

- economic security as an economic category has a relativistic character, since it exists in comparison;

- economic security matters only in the case of existing company with a certain market share;

- despite the dependence on many factors, the economic security of the enterprise acquires an individual character;

- problem of economic security arises in the case of a non-stationary non-deficit market, which is far from equilibrium.

It is proposed to apply a systematic approach to the study of economic security. The integrated economic security of an enterprise is understood as an integral characteristic of an enterprise, including the following parameters: financial and economic, information, technological, material финансово-экономическая безопасность, информационная, технологическая, материально-техническая, кадровая, эпидемиологическая безопасность, разработана концептуальная модель оценки финансово-экономической, комплексной безопасности предприятия. Проведена практическая реализация предложенных разработок. Рекомендуется использовать разработанную модель управления экономической безопасностью как модуль ERP системы предприятия.

Ключевые слова: ERP система, модель, финансово-экономическая безопасность, информационная, комплексная безопасность.

and technical, personnel and epidemiological security.

The study of methods for assessing economic security in the current crisis conditions, covering all key indicators of production efficiency, is an urgent task. For Russian and foreign scientific communities in the field of economics, the study of economic security will be relevant in the coming years of the post-pandemic period.

The purpose of the work is to study methods for assessing the economic security of enterprises and develop a model for assessing the complex economic security of enterprises

\section{Literature Review}

The theoretical basis for this study was the work of Russian and foreign authors: Alferyev D. and Khusainova E. (2020), Baierle I.C. et al, (2020), Bentamar A. and Ourahou O. (2020), Burdina A.A. (2006), Fedyanina M.A. (2019), Gilfanov M.T. (2013), Voronov D.S., et al (2016).

Alferyev D. and Khusainova E. (2020) raise issues of socio-economic and technological development in their works. They suggest using artificial intelligence technologies as a universal method. Thus, they agree that this instrument is capable of positively affecting the level of socioeconomic development of countries. Authors Baierle I.C. et al, (2020) in their studies reflect the competitiveness variables that are most influenced by innovation: internal aspects and market orientation of the enterprise. An innovation variable simultaneously affects more than one competitiveness construct. The authors propose to monitor and manage innovation 


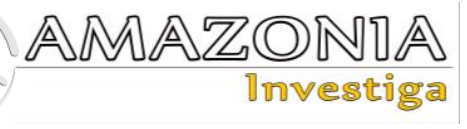

activities based on quantitative analysis. Bentamar A. and Ourahou O. (2020) in their works define the role of reverse logistics on the overall competitiveness of the enterprise and describe the factors that contribute to the deployment of reverse logistics. Authors Grodzicki M.J. and Skrzypek J. (2020) propose to assess the level of economic competitiveness based on the autoregressive distributed lags model.

Analysis of the works of various researchers allows concluding that they all tend to consider the safety of an enterprise within the framework of the components of its competitiveness, to apply holistic and quantitative methods of analysis. Improvement of processes in the production system Berić D., Stefanović D., Lalić B. and Ćosić I. (2018) see it as the need of the enterprise to provide supervision, control and management functions. For this, it is proposed to use Enterprise Resource Planning and Manufacturing Execution System.

\section{Methodology}

The integrated economic security management model consists of the following blocks:

1. scale of values of the complex economic security of the enterprise and its components is determined;

2. diagnostic procedure is carried out (analysis of the state of safety components);

3. procedure for "curing" the safety component is carried out: each component is assigned the necessary actions to improve its condition to the required level.

According to the methodology used for collecting and analyzing information, such types of research will be applied as quantitative, qualitative and mixed. The study of economic security as a process and phenomenon of an enterprise is supposed to be carried out taking into account the dynamics and interrelation of its components. At the first stage, the analytical group of the enterprise determines the purpose of the analysis, its scope and directions (components of economic security). At the second stage, the necessary information and approaches to assessing reporting indicators are collected. For the analysis of the problem, rational collection of information and obtaining quantitative estimates, it is proposed to use the methods of expert assessments. At the next stage, using the scale of values of the financial and economic security of the enterprise (the first block of the management model), an assessment of the complex economic security of the enterprise is determined. At the next stage, appropriate management decisions are developed and made. In 2021, a survey of the interest of oil and gas enterprises in conducting economic security analysis was conducted. Three enterprises answered the call. Experts were selected for each of the enterprises. Specialists and heads of enterprises were involved in the types of activities in which they specialize: financial and economic, information, technological, material and technical, personnel and epidemiological. The experts provided values for the indicators of operational efficiency, strategic position, etc. On the basis of their estimates, the work was carried out to test the study.

\section{Results and Discussion}

In the context of a new industrial model and stachosist threats to the financial and economic activities of aviation enterprises, the role of assessing their economic security is increasing. The assessment of economic security is relevant for Russian and foreign enterprises ones: that is, on a global scale. At this stage of development, five main tools and methods are recognized that can be applied in the framework of assessing economic security. These include methods of marketing assortment analysis: "ABC" method, "Matrix product portfolio design" or "BCG matrix" method, focused on categorizing an enterprise's product line in relation to the life cycle of a specific product (Tarasova et al., 2018). The management of an enterprise receives values within the framework of four categorical assessment systems, which characterize the profitability of a particular product of the enterprise and allow making decisions about its future fate. This method is widely known and no longer needs comments. The following methods are based on comparative analysis of product competitiveness (Lipinsky et al., 2020; Tikhonov, 2020). The competitiveness of products must be understood as a set of quality and cost characteristics that ensure the satisfaction of the specific needs of the buyer and differ favorably for the buyer from similar competing products. The assessment of competitiveness based on the level of sales is carried out using the ratio of the proportion of sales of the evaluated product in comparison with the competitor (1), the ratio of the useful effect of equipment and the price of consumption, etc. "CVP-analysis" method also successfully copes with the analysis of the economic security of an enterprise in the context of substantiating management decisions based on the study of the 
relationship between production volumes, costs and profits. "CVP analysis" allows determining the volume of break-even production, volume of production that ensures a given rate of return by the owners of the enterprise, margin of financial strength, etc. It is necessary to highlight the drawbacks of these methods: it is their complexity of the calculation both in time and in the input parameters of the calculation.

$$
K=\sum K_{\text {prod }} \times D_{\text {prod }},
$$

where $K_{\text {prod }}$ is the production volume, $D_{\text {prod }}$ is the share of products from total sales (individual weight).

Operational assessment methods are based on the theory of effective competition, which involves the assessment of the activities of all divisions of the enterprise from the standpoint of the rational use of available resources and operations that determine the economic activity of the enterprise (Martillo and Ramírez, 2018). The composition and structure of the assessed indicators may vary depending on the specific industry and research objectives. When assessing the economic security of an enterprise, each of the indicators is compared with a similar indicator of competitors (or reference value) (Berić et al., 2018; Ignatov, 2020). The partial efficiency ratios obtained in this way for each operation are subjected to mathematical processing, as a result of which the indicator of the economic security of the enterprise is calculated, which, more often than usual, is their weighted average value. In operational methods, various methods of statistical data processing and other methods of interpretation are used: graphs, diagrams, tables, polyhedrons, etc. (Grodzicki and Skrzypek, 2020; Sylkin et al., 2020).

The valuation method is based on the market value theory. The well-known business valuation tools (associated with the bottom line of the enterprise as a key motivating factor for investors) include the ratio of market value to earnings per share, return on investment and equity, earnings per share, economic value added, ratio of market to book value (Tarasova and Nikolenko, 2016; Gorelov et al., 2019).

Dynamic assessment methods are based on the definition of key indicators of the enterprise. The key indicators are the profitability of the enterprise (operational efficiency) and the change in the occupied market share (strategic positioning) (Pitakdumrongkit, 2020; Mishchuk et al., 2021). In this case, an assessment of the economic security of an organization can be made by multiplying the coefficients of operational efficiency and strategic positioning (Tarabrina et al., 2020). The assessment of the economic security of the enterprise is carried out for the reporting period and for several periods (Purcinelli et al., 2019).

We should also not forget about integral methods for assessing the economic security of a business, which are additive-multiplicative models that allow taking into account qualitative and quantitative characteristics. However, these methods are also laborious and require a highquality selection of an expert group (Tarasova et al., 2018).

In this work, we study the dynamic method developed by D.S. Voronov (Voronov et al., 2016; Tikhonov, 2020). The elements of this method form the basis of the developed model for assessing the complex economic security of enterprises.

The hypothesis of the research is that the parameters that determine the integrated economic security are: financial and economic security, information, technological, material and technical, personnel and epidemiological security. To assess these factors in the study, it is proposed to use training neural networks (Voronov et al., 2016; Tarabrina et al., 2020).

For a quantitative assessment of financial and economic security, it is proposed to use indicators of operational efficiency $\left(K_{R}\right)$, strategic positioning $\left(K_{I}\right)$ and financial condition $\left(K_{D}\right)$. The product of these indicators gives a single integrated indicator of the financial and economic security of the enterprise. $\left(S_{f e}(t)\right)$, reflecting the assessment of financial and economic security as a factor in the complex economic security of the analyzed company (Formula 2):

$$
S_{f e}(t)=K_{R} \times K_{I} \times K_{D} .
$$

The determination of the operational efficiency of a business $E_{o}$ is carried out using the formula:

$$
E_{o}=\frac{E_{A}}{E_{S}}
$$

where $E_{A}$ is the current operating efficiency of the business, $\% ; E_{S}$ is the current operating efficiency for a sample consisting of one or more competing enterprises or enterprises-competitors throughout the industry, $\%$. 


\section{AMAZOND周 \\ 1nvestiga}

The operating efficiency indicator $E_{o}$ is calculated as:

$$
E_{o}=\frac{S_{A}}{C_{A}},
$$

where $S_{A}$ is the current revenue, rubles; $C_{A}$ is the total of current costs, rubles. The total cost differs depending on the objectives of the analysis.

The operating efficiency of the sample for the reporting period is calculated as:

$$
E_{S}=\frac{S_{S}}{E_{S}}
$$

where $S_{S}$ is the current revenue for the group (sample), rubles; $E_{S}$ is the total costs for the group (sample) current, rubles.

Indicator of the strategic position of the enterprise in the market:

Table 1.

Scale of values of the financial and economic security of the enterprise (source: authors)

\begin{tabular}{ll}
\hline Values $S_{f e}(t)$ & Interpretation of the financial and economic security of the enterprise \\
\hline $0 \leq S_{f e}(t)<0.55$ & Critical \\
$0.55 \leq S_{f e}(t)<0.85$ & Low \\
$0.85 \leq S_{f e}(t)<1.2$ & Average \\
$1.2 \leq S_{f e}(t)$ & High \\
\hline
\end{tabular}

On the basis of the research carried out, a model for assessing complex economic security is being developed. The parameters of complex economic security are highlighted:

- $\quad$ financial and economic security, $S_{f e}(t)$;

- $\quad$ informational security, $S_{1}(t)$;

- $\quad$ technological security, $S_{2}(t)$;

- $\quad$ logistical security, $S_{3}(t)$;

Table 2.

Rating scale (source: authors)
- $\quad$ personnel security, $S_{4}(t)$;

- $\quad$ epidemiological security, $S_{5}(t)$.

The development of a methodological approach to the assessment of each parameter is carried out on the basis of neural network modeling. As a result of the study, a rating scale was developed (Table 2).

\begin{tabular}{ll}
\hline Values $S_{i}(t)$ & $\begin{array}{l}\text { Interpretation of information, technological, material and technical, personnel and } \\
\text { epidemiological security }\end{array}$ \\
\hline $0 \leq S_{i}(t)<0.4$ & Critical \\
$0.4 \leq S_{i}(t)<0.7$ & Low \\
$0.7 \leq S_{i}(t)<0.95$ & Average \\
$0.95 \leq S_{i}(t) \leq 1$ & High \\
\hline
\end{tabular}

Complex economic security of the enterprise $(C E S(t))$ determined using the following model:

$$
\operatorname{CES}(t)=S_{f e}(t) * \prod_{i=1}^{5}\left(1+S_{i}(t)\right)
$$

On the basis of the study, the scale of values of the complex economic security of the enterprise was determined (Table 3). 
Table 3.

Scale of values of the complex economic security of the enterprise (source: authors)

\begin{tabular}{ll}
\hline Values $C E S(t)$ & Interpretation of the complex economic security of the enterprise \\
\hline $0 \leq C E S(t)<2.96$ & Critical \\
$2.96 \leq C E S(t)<12.1$ & Low \\
$12.1 \leq C E S(t)<33.8$ & Average \\
$33.8 \leq C E S(t)$ & High \\
\hline
\end{tabular}

The developed dynamic method makes it possible to assess the complex economic security of an enterprise separately and in comparison with other companies of similar size. From a practical point of view, the results of the work carried out are of interest to the managers of the enterprise and to potential investors considering the acquisition of the enterprise. In their arsenal of methods for assessing economic security, there is another one that allows flexibly responding to changing market conditions and taking into account changing risks, helping to reflect the level of financial and economic security. A quantitative assessment of each of the factors of complex economic security is carried out by applying methods of neural network modeling.

The practical implementation of the integrated economic security assessment model was carried out at the following enterprises: Nizhnekamskneftekhim, Uralkali, PhosAgro. The calculation results are presented in the Table 4.

Table 4.

Assessment of complex economic security of enterprises (source: authors)

\begin{tabular}{|c|c|c|c|c|}
\hline \multirow{2}{*}{ Corporation } & \multicolumn{4}{|c|}{ Integrated economic security indicator } \\
\hline & 2016 & 2017 & 2018 & 2019 \\
\hline Nizhnekamskneftekhim & 20.34 & 19.12 & 18.54 & 19.13 \\
\hline Uralkali & 12.32 & 13.49 & 14.21 & 12.41 \\
\hline PhosAgro & 16.56 & 15.38 & 14.83 & 13.14 \\
\hline
\end{tabular}

The analysis showed that enterprises are characterized by an average level of complex economic security. Based on the results of the study of economic security by the integral indicator, it can be noted that corporations produce competitive products in the chemical industry. To increase economic security, companies need to ensure the economic security of their products in target market segments and raise the economic security potential of an enterprise to the top manufacturers in the industry.

\section{Conclusion}

The study examines one of the urgent problems of industrial enterprises in the context of digitalization of the external and internal environment: management of the economic security of the enterprise. It is substantiated that this is a multifactorial task. The author substantiates the original interpretation of the concept of "integrated economic security of an industrial enterprise", substantiates the problems of analyzing complex economic security in the context of the need for import substitution, technological and information dependence.
Deficiencies in approaches to assessing the integrated economic security of industrial enterprises are determined. The article examines methods for assessing economic security: matrix, product, operational, dynamic one and methods of assessment based on the market value of the company. Based on the classification of the parameters of the integrated economic security of an industrial enterprise: financial and economic security, information, technological, material and technical, personnel, epidemiological security, conceptual model for assessing the financial and economic, integrated security of an enterprise is proposed. This model is recommended to be used to substantiate management decisions in the field of economic security management and to integrate into the enterprise ERP system. The practical implementation of the proposed developments has been carried out.

\section{Bibliographic references}

Alferyev, D., and Khusainova, E. (2020). Ai technologies as a factor of competitiveness of a business entity at the present stage of human 


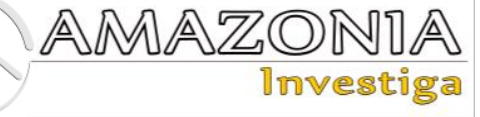

development. E3S Web of Conferences, 220, 01006.

Baierle, I. C., Benitez, G. B., Nara, E. O. B., Schaefer, J. L., and Sellitto, M. A. (2020). Influence of open innovation variables on the competitive edge of small and medium enterprises. Journal of Open Innovation: Technology, Market, and Complexity, 6(4), 179.

Bentamar, A., and Ourahou, O. (2020). Reverse Logistics and Competitivity Of The company: Literature Review. In 2020 IEEE 13th International Colloquium of Logistics and Supply Chain Management (LOGISTIQUA), 1-6.

Berić, D., Stefanović, D., Lalić, B., and Ćosić, I. (2018). The implementation of ERP and MES Systems as a support to industrial management systems. International Journal of Industrial Engineering and Management, 9(2), 77-86.

Burdina, A. A. (2006). The impact of risks on the economic security of the enterprise. Economic analysis: theory and practice, 2(59), 7-15. Available at https://cyberleninka.ru/article/n/vliyanieriskov-na-konkurentosposobnostpredpriyatiya

Fedyanina, M. A. (2019). Ways to improve the economic security of enterprises in Russia. Innovative science, 11, 76-77. Available at https://cyberleninka.ru/article/n/putipovysheniya-konkurentosposobnostipredpriyatiy-v-rossii

Gilfanov, M. T. (2013). Organizational and methodological tools for assessing determinants and ensuring the economic security of an enterprise. Socio-Economic Phenomena and Processes, 8(54), 19-27.

Gorelov, B., Davydov, A., Tikhonov, A., and Tuzhikov, E. (2019). Methods and models for evaluating the effectiveness of distributed systems of aviation equipment according to the "Cost-efficiency-time" criterion". Strategic Stability, 1(86), 20-25.

Grodzicki, M. J., and Skrzypek, J. (2020). Costcompetitiveness and structural change in value chains - vertically-integrated analysis of the European automotive sector. Structural Change and Economic Dynamics, 55, 276-287.

Ignatov, A. (2020). Entrepreneurial performance of the European Union-pivot of its economic security. New Medit, 19(2), 113-131.

Inchauspe, J., and Cronje, T. (2020). Concentration and Competition in the Australian Banking Industry: A BresnahanLau Structure-Conduct-Performance
Assessment. Economic Record, 96(315), 431-449.

Lipinsky, D. A., Magamedov, G. B., Suleimanov, B. B., and Musatkina, A. A. (2020). The Problems of Legal Regulation of Economic Security in the Context of Development of the Digital Economy. Public Administration and Regional Management in Russia. Cham: Springer, 469-476.

Martillo, W. A., and Ramírez, M. O. (2018). Model for the selection of an ERP system in the Malecon 2000 Foundation. Espacios, 39(37), 14.

Misakov, V., Tsurova, L., Yandarbayeva, L., Tkhamadokova, I., \& Gapurovna, G. (2019). Certification of a regional economic complex as a highly effective tool for analysis and diagnostics of its development. Amazonia Investiga, 8(20), 451-458. Retrieved from https://amazoniainvestiga.info/index.php/am azonia/article/view/174

Mishchuk, Y., Rebrova, S., Krush, P., Zinchenko, D., and Astafieva, K. (2021). Digitalization security as a marker of modern mechanical engineering technology implementation in the context of ensuring strategic economic security of enterprises. WSEAS Transactions on Business and Economics, 18(13), 117-125.

Pinkovetskaia, I., Arbeláez Campillo, D., Rojas Bahamón, M., Gromova, T., \& Nikitina, I. (2019). Female entrepreneurship development in the Russian Federation. Amazonia Investiga, 8(18), 111-118. Retrieved from https://amazoniainvestiga.info/index.php/am azonia/article/view/287

Pitakdumrongkit, K. (2020). What causes changes in international governance details: An economic security perspective. Review of International Political Economy, 1-26.

Purcinelli, L. M., Abreu, R., and Roux, A. M. (2019). Automation through an ERP system of the accounting and internal control procedures according with SOX Law. In 2019 14th Iberian Conference on Information Systems and Technologies (CISTI), 1-6.

Sylkin, O., Kryshtanovych, M., Petrovskyi, P., Sirant, M., \& Stetsyuk, N. (2020). The Methodology of Hierarchical Ordering of Threats to Economic Security as the Basis for Educational and Practical Application for the Management of IT Sphere Enterprises. In 2020 10th International Conference on Advanced Computer Information Technologies (ACIT), 639-642.

Tarabrina, N. Y., Kraev, Y. V., and Tikhonov, A. I. (2020). Physiological substantiation and practical implementation 
of methods of development of strengthbuilding component of endurance training for wrestlers. Theory and Practice of Physical Education, 2, 14-16.

Tarasova, E. V., and Nikolenko, T. Yu. (2016). The mechanism of forming the investment program of an industrial enterprise. Journal of the association of controllers "Controlling", 3(61), 34-43.

Tarasova, E. V., Nikolenko, T. Y., Gorbunov, G. L., and Semina, L. V. (2018). Implementation of investment projects at industrial enterprises. Russian engineering research, 38(4), 295-300.
Tikhonov, A. (2020). Corporate training programs in Russian and foreign companies: Impact on staff and time challenges. International Journal of Higher Education, 9(3), 183-189.

Voronov, D. S., Korsunov, P. P., Krivorotov, V. V. and Matveeva, T. V. (2016). Assessment and planning of economic security of enterprises of the fuel and energy complex. Yekaterinburg: Publishing House "Educational and Methodological Center of the Ural Polytechnic Institute". Available at https://www.elibrary.ru/item.asp?id=291100 25 